\title{
POTENSI WILAYAH DAN DAYA DUKUNG LAHAN DALAM MENUNJANG KETERSEDIAAN PAKAN TERNAK BAGI PENGEMBANGAN SAPI POTONG (STUDI KASUS DI KAMPUNG SAKABU KABUPATEN RAJA AMPAT)
}

\author{
REGION POTENTIAL AND LAND CAPACITY TO SUPPORT FORAGES \\ AVAIBILITY OF BEEF CATTLE DEVELOPMENT IN SAKABU VILLAGES \\ RAJA AMPAT REGENCY \\ Insun Sangadji ; Rajab
}

Jurusan Peternakan Fakultas Pertanian, Universitas Pattimura Jln. Ir. M. Putuhena, Kampus Poka - Ambon, Kode Pos. 97233 E-mail :insunsangadji@gmail.com

\begin{tabular}{l|l}
\hline Diterima: & Disetujui :
\end{tabular}

\begin{abstract}
Abstrak
Perkembangan ternak sapi potong berkorelasi positif dengan ketersediaan hijauan sebagai sumber pakan ternak. Penelitian ini bertujuan untuk mengetahui potensi wilayah dan daya dukung lahan dalam menunjang ketersediaan pakan ternak bagi pengembangan sapi potong yang dipelihara oleh penduduk lokal setempat di kampung Sakabu Distrik Salawati Kabupaten Raja Ampat. Penelitian menggunakan metode survei dengan cara pengamatan langsung di lapangan. Peubah yang diamati meliputi: iklim, jenis tanah dan topografi, luas lahan, sistem penggunaan lahan, dan daya dukung lahan (kapasitas tampung), serta populasi sapi potong yang dipelihara. Hasil penelitian menunjukkan potensi maksimum sumber daya lahan sebesar 6237,703 ST dan jumlah populasi yang ada sebanyak 35,2 ST. Berdasarkan hasil analisis potensi wilayah dan daya dukung lahan bagi penyediaan sumber pakan ternak maka jumlah sapi potong yang masih dapat dikembangkan di kampung Sakabu sebesar 6202,50 ST.
\end{abstract}

Kata kunci: Daya dukung lahan, ketersediaan pakan ternak, pengembangan sapi potong.

\begin{abstract}
Beef cattle development has positive correlation with forage avaibility as basic feed for ruminant life. This research aims were to know and analysis both region potential and land capacity to support forage avaibility of beef cattle which rearing by local breeder in Sakabu village Raja Ampat Regency. Field research built using survey method with direct observation of site object. The results showed that maximum land resources capacity potential rate was 6237.703 Animal Unit (AU) with the real number of beef cattle population was 35.2 AU. The concluded was due to the analisys of region and land capacity, then the number of beef cattle could be developed till 6202.50 AU.
\end{abstract}

Keywords: Land capacity, forage avaibility, beef cattle development. 


\section{PENDAHULUAN}

Sapi potong merupakan salah satu ternak ruminansia yang mempunyai peranan cukup strategis bagi kehidupan ekonomi sebagian masyarakat petani di pedesaan, sehingga perkembangan dan peningkatan produktivitasnya selalu menjadi perhatian (Bamualim, 2007). Dalam upaya mengembangkan usaha dan meningkatkan produktivitas sapi potong, maka perlu memperhatikan tiga hal utama yaitu tersedianya lahan, ternak (bibit), dan pakan (Soedrajat, 2000). Pemberian pakan sangat Salah satu sektor yang berpotensi dan sangat sesuai untuk dikembangkan di Kabupaten Raja Ampat adalah pertanian termasuk subsektor peternakan. Komoditas peternakan yang dapat dikembangkan di daerah ini adalah sapi potong. Kondisi wilayah yang luas memungkinkan pembentukan/pengembangan suatu kawasan budidaya sapi potong guna peningkatan ketahanan pangan untuk mewakili kebutuhan masyarakat akan

Kebutuhan asal ternak berupa daging, susu dan telur saat ini untuk penduduk Kabupaten Raja Ampat masih disuplai dari Kabupaten Sorong, karena mempengaruhi produktivitas dan kineja hewan ternak, di samping itu pakan ternak merupakan komponen biaya produksi terbesar dalam suatu usaha peternakan. Salah satu aspek yang penting dalam menunjang keberhasilan usaha peternakan adalah memberikan pakan yang berkualitas dengan jumlah pemberian sesuai dengan kebutuhan hewan ternak. Oleh karena itu pengetahuan tentang pakan dan pemberiannya perlu mendapat perhatian yang serius.

protein hewani, peningkatan pendapatan petani peternak dan pendapatan asli daerah (PAD) (Soltief, 2009). Sapi potong umumnya dipelihara secara ekstensif oleh masyarakat petani peternak di kabupaten ini dan bersifat sampingan dari kegiatan usaha tani atau perikanan sebagai usaha utama. Kondisi ini didukung oleh wilayah daratan yang masih luas dan sumber hijauan makanan ternak serta konsentrat yang belum termanfaatkan.

terbatasnya ketersediaan dari dalam. Populasi sapi potong di Kabupaten Raja Ampat terbanyak berada di Distrik Salawati Utara, dan salah satu 
wilayahnya adalah kampung Sakabu. Disparitas antara suplai dan potong perlu dilakukan. Potensi wilayah yang mendukung dan ketersediaan bahan baku pakan serta sumber daya manusia memungkinkan pengembangan sapi potong berbasis sumber daya lokal di wilayah tersebut. Hal ini karena perkembangan ternak sapi potong berkorelasi positif dengan ketersediaan hijauan sebagai sumber pakan ternak. Hijauan pakan merupakan bahan pakan utama yang perlu disediakan untuk ternak ruminansia. Hijauan pakan merupakan salah satu faktor yang mempengaruhi produktivitas ternak ruminansia. Pemenuhan kebutuhan hijauan pakan ternak dapat bersumber

\section{BAHAN DAN METODE}

Penelitian ini dilaksanakan selama tiga bulan dengan lokasi penelitian adalah Kampung Sakabu Distrik Salawati Utara Kabupaten Raja Ampat Provinsi Papua Barat. Pertimbangan pemilihan lokasi ini adalah (1) hampir sebagian besar Penelitian ini menggunakan metode survei dengan cara pengamatan langsung di lapangan yang dilakukan dengan cara pengukuran dan melihat permintaan/kebutuhan menunjukkan bahwa upaya pengembangan sapi

pada hijauan di sekitar lingkungan. Setiana (2014) menyatakan bahwa pemenuhan kebutuhan hijauan pakan diperlukan peningkatan pengelolaan hijauan pakan domestik berbasis ekosistem dan budaya masyarakat. Penelitian ini secara umum bertujuan untuk mengetahui potensi wilayah dan daya dukung lahan dalam menunjang ketersediaan pakan ternak bagi pengembangan sapi potong yang dipelihara oleh penduduk lokal setempat di kampung Sakabu Distrik Salawati Kabupaten Raja Ampat.

masyarakat mengusahakan sapi potong sebagai usaha sambilan keluarga, dan (2) berdasarkan RTRW Kabupaten Raja Ampat, lokasi ini diproyeksikan sebagai salah satu kawasan agropolitan dengan sentra pengembangan sapi potong di Kabupaten Raja Ampat (Bappeda Raja Ampat, 2007).

secara visual untuk menentukan kondisi dan pola pemeliharaan di lokasi penelitian dan padang penggembalaan. Data yang dikumpulkan mencakup data 
sekunder dan primer. Data sekunder diperoleh dari Bappeda Kabupaten Raja Ampat, Dinas Pertanian Peternakan dan Perkebunan Kabupaten Raja Ampat, BMG Kabupaten Sorong, dan BPS Kabupaten Raja Ampat. Data sekunder tersebut meliputi (1) karakteristik wilayah yang terdiri dari iklim dan

Peubah yang diamati dalam penelitian ini meliputi: iklim, jenis tanah dan topografi, luas lahan, sistem penggunaan lahan, dan daya dukung lahan (kapasitas tampung), serta populasi sapi potong yang dipelihara. Data yang diperoleh dianalisis secara deskriptif, dan disajikan dalam bentuk tabel. Kapasitas tampung ternak sapi potong dalam suatu wilayah menunjukkan populasi maksimum

1) $\mathrm{PMSL}=\mathrm{a} \mathrm{LG}+\mathrm{b} \mathrm{PR}+\mathrm{c} \mathrm{LH}$

Keterangan :

PMSL = Potensi maksimum berdasarkan sumber daya lahan (ST).

$\mathrm{a}=$ Daya tampung ternak ruminansia di lahan garapan $(\mathrm{ST}), \mathrm{a}=0,077 \mathrm{ST} / \mathrm{ha}$ lahan pekarangan; $\mathrm{a}=0,082 \mathrm{ST} / \mathrm{ha}$ lahan perkebunan; $\mathrm{a}=1,52 \mathrm{ST} / \mathrm{ha}$ lahan sawah.

LG = Luas lahan garapan (ha)

$\mathrm{b}=$ Daya tampung ternak ruminansia di lahan padang rumput (ST). $b=0,5$ $\mathrm{ST} /$ ha rumput alam $; \mathrm{b}=1 \mathrm{ST} / \mathrm{ha}$ alangalang

$\mathrm{PR}=$ Luas padang rumput/tegalan (ha)

$\mathrm{c}=$ Daya tampung ternak ruminansia di lahan hutan dan rawa (ST), $c=2,86$ ST/ ha lahan. topografi, dan (2) system penggunaan lahan. Data primer adalah hasil pengamatan dan pengukuran serta wawancara dengan responden, yakni (1) jumlah populasi sapi potong yang diusahakan, dan (2) pola pemeliharaan sapi potong.

ternak sapi potong yang dapat ada di wilayah tersebut berdasarkan ketersediaan pakan hijauan. Untuk mengetahui kapasitas pengembangan ternak sapi potong, data yang diperoleh dianalisis lebih lanjut dengan menggunakan penghitungan Kapasitas Peningkatan Populasi Ternak Ruminansia (KPPTR) mengacu pada Direktorat Jenderal Peternakan (1994), sebagai berikut:

LH = Luas lahan hutan dan rawa (ha)

2) $\operatorname{KPPTR}(\mathrm{SL})=$ PMSL - POPRIL

Keterangan :

KPPTR = Kapasitas peningkatan populasi ternak ruminansia berdasarkan sumber daya lahan (ST)

POPRIL = Populasi riil ternak ruminansia

3) $\mathrm{PMKK}=\mathrm{a} \times \mathrm{KK}$

Keterangan ;

PMKK = Potensi maksimum usaha ternak

(ST) berdasarkan kepala keluarga

KK = Kepala Keluarga

$\mathrm{a}=$ Kemampuan rumah tangga untuk usaha ternak rumnansia tanpa tenaga kerja dari luar rumah tangga $a=3 \mathrm{ST} / \mathrm{KK}$ 
HASIL DAN PEMBAHASAN

\section{Karakteristik Wilayah Penelitian}

Berdasarkan Rencana Tata

Ruang Wilayah (RTRW) Kabupaten Raja Ampat, Distrik Salawati Utara ditetapkan sebagai kawasan agropolitan yaitu sebagai wilayah pengembangan peternakan seperti sapi potong dan kawasan pengembangan pertanian

Kampung Sakabu berada di pesisir pantai dan umumnya dihuni oleh masyarakat pribumi (asli Papua). Secara umum, kondisi iklim, jenis tanah dan topografi Kampung Sakabu dapat dilihat pada Tabel 1. Secara geografis Kampung Sakabu memiliki iklim tropis yang lembab dan panas, curah hujan relatif tinggi $( \pm 211.42 \mathrm{~mm} /$ bulan$)$ dan merata sepanjang tahun. Kondisi ini sangat mendukung pertumbuhan

Hidayati dkk. (2007) mengemukakan bahwa saat terbaik bagi pertumbuhan dan produksi padang rumput bagi hijauan makanan ternak dan leguminosa berada pada kondisi iklim dengan temperature $27{ }^{\circ} \mathrm{C}$, kelembaban antara $70-80 \%$ dan radiasi matahari $60-80 \%$. Keadaan ini sesuai dengan kondisi optimal untuk sapi potong daerah tropis guna tanaman pangan khususnya padi dan perkebunan. Wilayah Distrik Salawati Utara ditetapkan sebagai kawasan pengembangan peternakan khususnya sapi potong mencakup tiga kampung yaitu kampung Sakabu, Kalobo dan Waijan (Bappeda Raja Ampat, 2007). Ketiga kampung ini terletak di sebelah selatan Pulau Salawati dan saling berbatasan satu dengan lainnya.

hijauan dan leguminosa sehingga dapat menjamin ketersediaan dan kontinuitasnya sebagai sumber pakan ternak sapi potong sepanjang tahun. Rata-rata temperatur udara $27,4{ }^{\circ} \mathrm{C}$ dengan kisaran temperatur terendah sebesar 23,9 ${ }^{\circ} \mathrm{C}$ dan tertinggi sebesar $33,1{ }^{\circ} \mathrm{C}$. Kelembaban berkisar antara 79 $\%$ - $87 \%$ dengan rata-rata radiasi penyinaran matahari sebesar $60 \%$ tiap tahun.

mendukung aktifitas reproduksinya (Talib dkk., 1999). Disamping itu, kondisi iklim ini sangat memungkinkan bagi pengembangan sapi potong lokal Indonesia (sapi Bali) karena sapi lokal pada umumnya mempunyai kemampuan beradaptasi baik pada lingkungan iklim tropis dengan ketersediaan pakan berkualitas rendah (Handiwirawan dan Subandriyo, 2004). 
Tabel 1. Kondisi iklim, Jenis Tanah dan Topografi Lokasi Penelitian

\begin{tabular}{ccc}
\hline No & \multicolumn{1}{c}{ Peubah yang Diamati } & Lokasi Kampung Sakabu \\
\hline 1 & Iklim & 2537 \\
& a. Curah hujan $(\mathrm{mm} / \mathrm{thn})$ & 27,7 \\
& b. Temperatur rata-rata $\left({ }^{\circ} \mathrm{C}\right)$ & 84 \\
& c. Kelembaban $(\%)$ & 1010,7 \\
& d. Tekanan udara (mbs) & 60 \\
e. Penyinaran matahari $(\%)$ & \\
& Jenis tanah dan topografi & $0-25$ \\
a. Ketinggian tempat $(\mathrm{dpl})$ & $0-40$ \\
b. Kemiringan lahan $(\%)$ & Podsolik+Aluvial \\
& c. Jenis tanah & Sedang \\
& d. Tekstur tanah & Subur, sedang \\
& e. Tingkat kesuburan & $0-100$ \\
& f. Kedalaman efektif $(\mathrm{cm})$ & Agak rendah \\
\hline
\end{tabular}

Sumber: Bappeda Kabupaten Raja Ampat (2016)

Topografi Kampung Sakabu umumnya merupakan dataran rendah disertai areal perbukitan, dengan ketinggian antara 0 sampai $25 \mathrm{~m} \mathrm{dpl}$ serta kemiringan lahan antara $0-40 \%$. Hasil estimasi selama penelitian, diperkirakan kondisi lahan yang datar sebesar $45 \%$ sedangkan sisanya $(65 \%)$ merupakan daerah perbukitan dengan ketinggian kurang dari $25 \mathrm{~m}$ dpl. Jenis

Menurut Harjowigeno dan Widiatmaka (2006), kondisi media perakaran yang sesuai untuk padang penggembalaan yaitu tekstur tanah sedang (lempung liat berpasir), kedalaman efektif $>30 \mathrm{~cm}$, dan drainase tanah agak terhambat sampai sedang. Secara umum kondisi Kampung tanah adalah podsolik berwarna merah kuning dan aluvial coklat dengan tekstur tanah sedang, menunjukkan tingkat kesuburannya yang sedang sampai subur. Air tersedia secara cukup untuk memenuhi kebutuhan konsumsi air minum ternak,memandikan/membersihkan ternak, pertumbuhan hijauan pakan ternak, dan kebutuhan lainnya.

Sakabu yang didominasi oleh wilayah yang datar akan sangat cocok bagi pengembangan sapi potong, apalagi dengan didukung oleh $\pm 50-60 \%$ daerah dataran yang berupa padang rumput sebagai sumber pakan sapi potong. 
Potensi Wilayah dan Daya Dukung

\section{Lahan}

Hasil survei menunjukkan bahwa luas lahan kampung Sakabu adalah sebesar 2,887 ha (Tabel 2). Sumberdaya lahan yang dapat dimanfaatkan untuk ternak ruminansia antara lain : lahan sawah, padang pengembalaan/padang rumput, lahan perkebunan, hutan dan lahan pekarangan. Luas lahan tersebut dengan tingkat kepadatan penduduk yang relatif masih rendah $\quad(\leq 10 \quad$ jiwa $/ \mathrm{km} 2)$ memungkinkan pengembangan sapi potong melalui pola integrasi ternak dengan tanaman perkebunan dan atau pertanian dan perikanan di kampung Sakabu, yang mana pola integrasi ini merupakan suatu proses saling menunjang dan saling menguntungkan. Pemanfaatan pola integrasi diharapkan dapat meningkatkan ketersediaan pakan sepanjang tahun, sehingga dapat meningkatkan produktivitas ternak (Riady, 2004).

Tabel 2. Potensi wilayah dan daya dukung lahan lokasi penelitian

\begin{tabular}{|c|c|c|}
\hline No & Peubah yang Diamati & Lokasi Kampung Sakabu \\
\hline 1 & Luas Lahan $(\mathrm{Ha})$ & 2.887 \\
\hline 2 & Jumlah Penduduk (KK) & 97 \\
\hline 3 & Jumlah Penduduk (Jiwa) & 394 \\
\hline 4 & Kepadatan Penduduk (jiwa/km2) & 10,8 \\
\hline 5 & Luas Lahan Pangan $(\mathrm{Ha})$ & 83 \\
\hline \multirow[t]{2}{*}{6} & Nisbah Lahan Pangan Terhadap & 4,75 \\
\hline & Penduduk (jiwa/ha) & \\
\hline \multirow[t]{6}{*}{7} & Tata Guna Lahan : & \\
\hline & a. Luas hutan (Ha) & 2057 \\
\hline & b. Luas padang rumput $(\mathrm{Ha})$ & 686 \\
\hline & c. Luas sawah $(\mathrm{Ha})$ & 0 \\
\hline & d. Luas perkebunan (Ha) & 119 \\
\hline & e. Luas pekarangan $(\mathrm{Ha})$ & 25 \\
\hline 8 & $\operatorname{PMSL}(\mathrm{ST})^{\mathrm{a}}$ & 6237,703 \\
\hline 9 & Populasi saat penelitian (ST) & 35,2 \\
\hline 10 & $\operatorname{KPPTR}(\mathrm{ST})^{\mathrm{b}}$ & 6202,50 \\
\hline 11 & $\operatorname{PMKK}(\mathrm{ST})^{\mathrm{c}}$ & 291 \\
\hline 12 & Pola dasar Pembangunan & Lahan Pertanian dan pemukiman \\
\hline 13 & Pola Pertanian & $\begin{array}{l}\text { Perikanan tradisional dan } \\
\text { pertanian non persawahan }\end{array}$ \\
\hline 14 & Sarana Irigasi & Non-irigasi \\
\hline ran & $\begin{array}{cc}\text { a. } & P M S L=\text { Potensi Maksimum berdasarkan S } \\
\text { b. } & \text { KPPTR = Kapasitas Peningkatan Populasi } \\
\text { c. } & \text { PMKK = Potensi Maksimum Usaha Ternak }\end{array}$ & $\begin{array}{l}\text { Daya Lahan } \\
\text { k Ruminansia } \\
\text { isarkan Kepala }\end{array}$ \\
\hline
\end{tabular}


Sudah saatnya peruntukan pemanfaatan lahan harus dilakukan dengan menerapkan tingkat kesesuain lahan melalui pengkajian yang mendalam dan tidak terpola pada kepentingan sesaat. Optimalisasi pemanfaatan lahan tidak lagi secara monokultur tetapi dilakukan dengan sistem yang terintegrasi dengan komoditas lain, seperti pertanian atau sumber daya perikanan sebagai sumber Pada usaha sapi potong, lahan merupakan basis untuk usaha tersebut atau merupakan faktor produksi sebagai sumber pakan pokok. Lahan dapat berfungsi sebagai tempat terselenggaranya kegiatan produksi. Kebutuhan lahan bagi pengembangan ternak ruminansia seperti sapi potong adalah penting terutama sebagai sumber pakan seperti rumput (graminae), leguminosa dan hijauan dari tumbuhan lain seperti daun nangka, daun waru dan lain sebagainya (Soekartawi dkk., 1986). Berdasarkan hasil survey, rata rata produksi gabah kering giling sebesar 2,5 ton/ha/panen yang Lahan perkebunan terbagi atas kebun tanaman durian dan sagu, namun lebih di dominasi oleh tanaman sagu $( \pm 70 \%)$, dari luasan ini. Produksi ampas pakan bagi ternak ruminansia seperti halnya sapi potong yang diusahakan oleh penduduk lokal di Kampung Sakabu. Menurut Rayes (2007), lahan merupakan lingkungan fisik yang meliputi tanah, iklim, relief, hidrologi dan vegetasi yang mempengaruhi potensi penggunaannya, termasuk didalamnya adalah akibat-akibat kegiatan manusia.

diproduksi oleh petani di wilayah sekitar Kampung Sakabu yaitu Kalobo dan Waijan. Hasil ini dapat menghasilkan limbah berupa dedak padi sebanyak 472 ton, dengan demikian jumlah ini dapat digunakan sebagai pakan konsentrat untuk 2.098 ST sapi potong. Disamping itu produksi jerami padi dapat mencapai 7.221 ton/panen. yang menurut Sumanto dkk. (2005) setiap hektar sawah mampu menghasilkan jerami padi 5-8 ton/ha/panen. Jerami padi ini dapat digunakan sebagai pakan alternative untuk \pm 2.865.7 ST sepanjang tahun.

sagu dengan kadar air $40 \%$ dapat mencapai 89.000 ton. Rata-rata tanaman sagu di panen 73 batang/ha/tahun (Bintoro, 2008). Menurut Saitoh et al. 
(2004) perbandingan pati dan ampas dari tanaman sagu adalah $1: 5$ dengan rata-rata produksi pati untuk tanaman sagu di wilayah Papua 600 kg/batang. Berdasarkan jumlah produksi ampas sagu tersebut, dapat digunakan sebagai pakan ternak sapi untuk 123.611 ST sepanjang tahun. Sistem penggunaan lahan di lokasi penelitian terbagi atas lahan usaha dan lahan pekarangan Kebutuhan lahan untuk usaha ternak ruminansia dapat dibedakan menjadi dua: 1) usaha peternakan yang berbasis lahan pertanian (land base agriculture); dan 2) usaha peternakan yang tidak berbasis lahan pertanian (non land base agriculture). Menurut Suratman dkk. (1998), khusus untuk peternakan berbasis lahan pertanian dengan komponen pakannya sebagian besar terdiri atas tanaman hijauan (rumput dan leguminosa), lahan merupakan factor lingkungan hidup dan pendukung pakan. Agar ternak dapat berproduksi dengan baik, perlu diperhatikan persyaratan penggunaan dari sifat-sifat pembatas lahan yang Hasil analisis daya dukung lahan/wilayah berdasarkan atas potensi maksimum sumber daya lahan dan kemampuan menghasilkan hijauan pakan ternak secara alami. dengan status kepemilikan lahan berupa hak ulayat bagi penduduk asli di Kampung Sakabu. Umumnya lahan usaha hanya sebagian kecil saja yang dipergunakan untuk pertanian dan selebihnya tidak digarap. Kondisi ini umumnya dimanfaatkan sebagai areal penggembalaan ternak karena hijauan makanan ternak sebagai sumber pakan sapi potong selalu tersedia.

meliputi kelompok kualitas lahan yang diperlukan dan yang mempunyai pengaruh merugikan untuk produksi ternak. Menurut Hardjowigeno dan Widiatmaka (2001), kualitas lahan yang perlu diperhatikan untuk produksi ternak adalah: 1) tersedianya semua unsur yang diperlukan untuk pertumbuhan tanaman; 2) kesesuaian iklim yang mempengaruhi ternak; 3) ketersediaan air minum ternak; 4) nilai nutrisi rumput; 5) sifat racun dari rumput; 6) penyakit-penyakit hewan; 7) ketahanan terhadap kerusakan rumput; dan 8) ketahanan erosi akibat penggembalaan.

menunjukkan bahwa populasi sapi potong dan daya tampung wilayah untuk ternak sapi potong di Kampung Sakabu masih cukup memadai sebagaimana disajikan pada Tabel 2. 
Berdasarkan hasil analisis, jumlah ternak sapi potong yang masih dapat dikembangkan di kampung Sakabu sebesar 6202,50 ST. Apabila pembangunan peternakan diarahkan pada pengembangan sapi potong dengan pola integrasi atau secara intensifikasi,

\section{KESIMPULAN}

$$
\text { Berdasarkan hasil analisis }
$$

potensi wilayah dan daya dukung lahan

\section{DAFTAR PUSTAKA}

Bamualim, A.M. 2007. Produksi Peternakan Di Indonesia: Potensi dan Kendala. Prosiding Seminar Nasional Teknologi Peternakan dan Veteriner. Bogor: 21-22 Agu 2007. Hlm: 13-14.

[Bappeda] Badan Perencanaan Pembangunan Kabupaten Raja Ampat. 2007. Rencana Tata Ruang Wilayah Kabupaten Raja Ampat. Waisai: Pemerintah Daerah Kabupaten Raja Ampat.

[Bappeda] Badan Perencanaan Pembangunan Kabupaten Raja Ampat . 2016. Kabupaten Raja Ampat dalam Angka 2015. Waisai: Pemerintah Daerah Kabupaten Raja Ampat.

Bintoro H.M.H. 2008. Bercocok Tanam Sagu. Program Kerjasama Sekolah Pascasarjana Institut Pertanian Bogor dan Universitas Tokyo. Bogor : IPB Press. daya tampung tersebut masih dapat ditingkatkan. Dengan demikian dari jumlah tersebut terlihat bahwa lokasi penelitian cukup potensial untuk dikembangkan menjadi kawasan pengembangan sapi potong.

bagi penyediaan sumber pakan ternak maka jumlah sapi potong yang masih dapat dikembangkan di kampung Sakabu sebesar 6202,50 ST.

Handiwirawan E., dan Subandriyo. 2004. Potensi dan keragaman sumberdaya genetic sapi Bali: Strategi Pengembangan Sapi Potong dengan Pendekatan Agribisnis dan Berkelanjutan. Prosiding Lokakarya Nasional Sapi Potong. Yogyakarta, 8-9 Oktb 2004. Hlm 51-56.

Hardjowigeno S., dan Widiatmaka, 2001. Kesesuaian Lahan dan Perencanaan Tataguna Lahan. Bogor: Institut Pertanian Bogor (IPB) Press.

Hidayati Nuril, C.Talib, dan A.Pohan. 2007. Produktivitas Padang Penggembalaan Rumput Alam untuk Menghasilkan Sapi Bibit di Kupang Timur, Nusa Tenggara Timur. Prosiding Seminar Nasional Teknologi Peternakan dan Veteriner; Bogor, 17-18 Sept. 2007. Hlm 345-352.

Rayes M.L, 2007. Metode Inventarisasi Sumber Daya lahan. Yogyakarta: Andi Publisher. 
Riady M. 2004. Tantangan Dan Peluang Peningkatan Produksi Sapi Potong Menuju 2020. Prosiding Lokakarya Nasional Sapi Potong. Yogyakarta: 8-9 Okt 2004, Hlm 3-6.

Saitoh K., M.H. Bintoro, F.S. Jong, Hazairin, J. Louw dan N. Sugiyama. 2004. Studies on the Starch productivity of Sago Palm in Riau, West Kalimantan and Irian Jaya. Journal Tropical Agriculture 48(2):1-2.

Setiana, MA. 2014. Peran strategis hijauan pakan domestik. Prosiding Seminar Nasional III HIPTI. Padang (ID): Himpunan Ilmuan Pakan Ternak Indonesia.

Soedrajat, S. 2000. Potensi dan Prospek Bahan Pakan Lokal dalam Memgembangkan Industri Peternakan Di Indonesia. Buletin Peternakan. Edisi Tambahan: 11-15.

Soekartawi, A. Soeharjo, J. L. Dillon, dan J. B. Hardaker. 1986. Ilmu Usaha Tani dan Penelitian untuk Pengembangan Petani Kecil. Jakarta: UI-Press.

Soltief, M.S. 2009. Kajian Kawasan Sapi Potong Di Kabupaten Raja Ampat Provinsi Papua Barat. [Tesis]. Bogor: Sekolah Pascasarjana, Institut Pertanian Bogor.

Sumanto, Rosita Galib, dan Arif Darmawan. 2005. Pengkajian Integrasi Padi-Sapi di Lahan Sawah Tadah Hujan Kalimantan Selatan. Prosiding Seminar Nasional Teknologi Peternakan dan Veteriner. Bogor: 12-13 Sept 2005. Hlm 232-240.
Suratman, S., Ritung, dan Jaenudin. 1998. Potensi lahan untuk pengembangan ternak ruminansia besar di beberapa provinsi di Indonesia. Prosiding Peternakan Pembangunan dan Komunikasi Hasil Penelitian Tanah dan Agroklimat. Bidang Pedologi. Cisarua: 4-6 Maret 1998. Hlm 169-182. Bogor: Pusat Penelitian Tanah dan Agroklimat.

Talib C., A. Bamualim, dan A. Pohan. 1999.

Problematika Pengembangan Sapi Bali dalam Pemeliharaan Di Padang Penggembalaan. Prosiding Seminar Nasional Teknologi Peternakan dan Veteriner. Hal 28. Bogor: Puslitbangnak. 